\title{
Examination of Lifelong Learning Trends of Physical Education and Sports Teachers on Different Variables
}

\author{
Alpay BÜLBÜL ${ }^{1}$ \\ ${ }^{1}$ Faculty of Sport Education, Sinop Univeristy, Sinop, Turkey \\ Correspondence: Alpay BÜlBÜL, Faculty of Sport Education, Sinop Univeristy, Sinop, Turkey. E-mail: \\ alpaybulbul60@hotmail.com
}

Received: September 19, 2020 Accepted: October 22, 2020 Online Published: November 12, 2020

doi:10.5539/jel.v9n6p94 URL: https://doi.org/10.5539/jel.v9n6p94

\begin{abstract}
Objective: The aim of this study is to examine the lifelong learning trends of physical education and sports teachers with regard to various variables and to compare them with the literature.

Method: 113 physical education teachers working in secondary schools and high schools in Tokat province and its districts during the 2019-2020 academic year participated in the study. In order to obtain the research data, the "Lifelong Learning Scale" adapted to Turkish by Engin, Kör and Erbay (2016) and the demographic information questionnaire created by the researchers were used. This research is a descriptive study in scanning model. The research data were subjected to normality test and the research data were analyzed according to the results. In the analysis of the data, 0.05 significance level was taken as the criterion. In order to determine the level of lifelong learning competence of physical education and sports teachers, the variables with 2 level were analyzed by using $t$ test statistics, and the variables with 3 or more levels were analyzed by the ANOVA F test statistic.

Conclusion: According to the results of this study which was conducted on different variables, physical education teachers' lifelong learning tendency scores are high. At the same time; gender, professional seniority and and the lvel of the institution (primary school, high school etc.) are not effective factors on lifelong learning motivations og physical education and sports teachers.
\end{abstract}

Keywords: lifelong learning, teacher, manner

\section{Introduction}

The period of time, in which the individuals voluntarily or involuntarily commit the hearsay or proven information to their memories through their social environment, family or formal school, can be described as the learning process. In this context, life can be explained as a development process and the development can be explained as the life itself. Development refers to the formation of habits, the clarification of interests and the development of the power of observation and thinking (Dewey, 2004, pp. 10-14). Additionally, there are many changes that have taken place in our age and that we need to keep up with; and individuals should follow these changes and developments for the purpose of keeping up with the society. The most important of these are internet, informatics and science. Rapid changes in science and technology change the social, cultural and economic paradigms, and individuals' expectations are also affected by this change (Uzunboylu \& Hürsen, 2011). All these changes interest every society in the world and in this way, societies of knowledge come into existence. In the information age, rapid changes and developments in information and communication technologies cause individuals to be in need of continuous learning. It is compulsory that individuals have learning skills in a shorter time in order to cope with the increasing volume of information through the internet and other information and communication technologies (Cornford, 2002; Budak, 2009). For this reason, individuals who are needed in the information technology, who can rapidly adapt to the changing technology, who can constantly renew themselves and who have analytical and questioning skills should be raised (Demiralay \& Karadeniz, 2008).

This situation has led to the formation of the "Lifelong Learning" concept which enables the individuals to obtain the knowledge and skills they need at all ages (Coşkun \& Demirel, 2012). Lifelong learning was mentioned for the first time at the conference organized by UNESCO. In this conference, which was held in 
Hamburg, the concept of lifelong learning was reconsidered by the UNESCO Education Institute. Later, in the 1970s and 1980s, theoretical and practical studies on lifelong learning were conducted (Ohidy, 2008; Akt, Günüç, Odabaşı, \& Kuzu, 2012). As from the 1990s, the European Union has adopted lifelong learning as the basic criterion of cooperation in education and training (Pepin, 2007). Lifelong Learning is heavily emphasized as an important slogan in the European Union education and training policies (Dehmel, 2006). In 2019, Turkey prepared a "Lifelong Learning Strategy Document" in accordance with the Strategy Plan of Ministry of National Education. The main purpose of this document was to create different learning environments where individuals could improve their knowledge and skills (Cansever, 2009). Lifelong learning includes all learning activities carried out formally or informally in order to improve knowledge, skills and abilities (European Commission, 2002). In other words, it includes the skills of accessing, using and evaluating the necessary information from various sources for the purpose of being adapted to the rapidly changing economic, political, cultural and technological environment (Ohsako \& Mauch, 2001; Odabaş \& Polat, 2008). Lifelong learning can also be described as supporting the new ways of learning with information communication Technologies. Lifelong learning is the educational activities that can be carried out anywhere in accordance with the interests and needs of the individuals in all segments of the society. In addition to providing individuals with knowledge and skills, these activities also have the function of bringing them into society and making them a part of the society (Demirel \& Yağc1, 2012).

When the literature is examined in general, it is seen that some of the studies have handled the the approaches of undergraduate, postgraduate and college students to lifelong learning (Gustafson, 1992; Code, 2001; Harwood, 2007; Coşkun \& Demirel, 2012; İzci \& Koç, 2012). It is also seen that the other part of the studies on the subject, emphasized the importance of lifelong learning being at the center of basic education policies (Cornford, 2002; Dehmel, 2006; Pepin, 2007; Cansever, 2009; Budak, 2009; Arcuria, 2011; Sağlam, Özdoğru, \& Çıray, 2011). Besides, there are also studies, which describe the importance of lifelong learning regarding information literacy (Demirel \& Karadeniz, 2008), and training of the educators (Soran, Akkoyunlu, \& Kavak, 2006). Lifelong learning competencies motivate the individuals to learn or the idea of learning and to support these ideas of them rather than combining the understanding of traditional education programs with contemporary learning opportunities (Avrupa Komisyonu, 2002). The competencies of lifelong learning should be provided to students as from primary education. In this context, qualifications of the teachers should be discussed and questioned (Budak, 2009). The diversification of the expectations and needs of the individual in parallel with the technological advancements and the expansion of access to information, necessitates the inclusion of lifelong learning programs in the curricula of universities (Jarvis, 2007). When the fundamental role of lifelong learning in fulfilling the present and future needs of the society is considered (Harwood, 2007), it is of great importance to bring these competencies to teachers (Şahin \& Arcagök, 2014).

Lifelong learning is a process that enables to take advantage of all learning opportunities that are an indispensable part of life and improves the individual (Demirel, 2011). The role of the teacher in lifelong learning is of great importance. Teachers should explain how valuable the knowledge is and show students the shortest and most accurate ways to access information with appropriate strategies, methods and techniques. The individual should always be aware that $\mathrm{s} /$ he needs information. S/he should understand the necessity of lifelong learning to solve the problems s/he encounters (Fındıkçı, 2004). Education programs need to guide students in subjects such as versatile, abstract, critical, creative, independent thinking, problem solving, gaining effective communication skills, knowledge generation, learning to learn, feeling themselves valued, trusting their capacities and valuing the differences which can be achieved by lifelong learning (Özden, 2005).

In addition, some characteristics that should be sought in individuals with lifelong learning tendencies are emphasized. According to Knapper and Cropley (2000), in the literature review, the lifelong learners are the individuals who question their learning, actively participate in the process, learn by planning their own learning, learn from their relatives, teachers, friends, in short, from their environment, and are sensitive to different ways of learning. Additionally, Candy (1994) states that lifelong learners have a love of learning, can create a sensitive connection between a broad vision and various fields of knowledge, can rearrange and evaluate the information, have a positive self-perception, have organizational skills and use their learning strategies at each stage of learning (Ayaz, 2016).

As a result of the field review, there was a need for such a study, since there was no comprehensive research on lifelong learning tendencies of physical education and sports teachers. The purpose of this study is to customize the lifelong learning tendency on physical education and sports teachers in addition to all literature studies and to fill the gap in the field. The aim of the study is to show the extent to which physical education teachers' lifelong learning is affected by these variables. 


\section{Method}

In this section, information about the research model, the population and sample of the research, the collection and analysis of the research data were given.

\subsection{Research Model}

This research is a descriptive study conducted by using a screening model in which the lifelong learning tendencies of teachers are examined. Screening models are the research approaches that aim to define a past or present situation as it exists (Karasar, 2009).

\subsection{Population and Sample}

The population of the study is consisted of physical education and sports teachers working at the city center and districts of Tokat province in 2020-2021. The sample of the study is consisted of 113 teachers who were selected randomly.

\subsection{Data Collection Tool}

"Lifelong Learning Scale" which was developed by Wielkiewicz and Meuwissen (2014) and adapted to Turkish by Engin, Kör and Erbay (2016) was applied in the study. The Lifelong Learning Scale is a one-dimensional scale with 15 articles. In the same study, it was stated that the purpose of this scale was to evaluate the lifelong learning of the students and people in the other group. The scale has a 5 points of Likert type with the ratings as (1) never, (2) rarely, (3) occasionally, (4) often, and (5) always. For example, the Cronbach alpha coefficient of the scale is 0.936 and the Kaiser-Meyer-Olkin (KMO) value is 0.95 . The total variable as a result of the single factor solution of factor analysis is 52.651. Accordingly, when the factor loads are examined, it is revealed that these loads are between 0.660 and 0.795 . The normality assumptions of the scale are as follows;

Table 1. Normality test results of the scale

\begin{tabular}{ll}
\hline & Scale \\
\hline Average & 60.55 \\
Standard Deviation & 8.026 \\
Kolmogorov Smirnov Test & 1.243 \\
p value & 0.091 \\
\hline
\end{tabular}

Looking at Table 1, the scale is of the normal distribution $(\mathrm{p}=0.091>\alpha=0.05)$.

\subsection{Data Analysis}

All statistical analyzes performed during the data analysis phase were carried out via the SPSS20.0 statistics program. The results obtained in the analysis of the research data were shown in the tables. In the data analysis, 0.05 significance level was taken as the criterion. For the purpose of determining the level of lifelong learning competence of physical education and sports teachers, variables with a level number of 2 were analyzed with the t-test statistic, and variables with 3 or more level numbers were analyzed with the ANOVA F test statistics.

\section{Findings}

The findings obtained from the research were handled according to the demographic features of the research participants and their independent variables and shown in the form of tables.

Table 2. Distributions of demographic variables

\begin{tabular}{llll}
\hline & Variable & Frequency(n) & Percentage (\%) \\
\hline Gender & Female & 29 & 28.2 \\
& Male & 74 & 71.8 \\
Institution & Secondary School & 59 & 57.3 \\
\multirow{3}{*}{ Year of Profession } & High School & 44 & 42.7 \\
& 1-5 Years & 26 & 25.2 \\
& 6-10 Years & 32 & 31.1 \\
& 11-15 Years & 12 & 11.7 \\
& 16-20 Years & 33 & 32.0 \\
\hline
\end{tabular}


Looking at the distribution of the gender variable of those who participated in the survey, 71.8 , that is, 74 of the participants are males while $28.2 \%$, that is, 29 of the participants are females. Looking at the distribution of the institution variable, $42.7 \%$, that is 44 of the participants are working at high schools while $57.3 \%$, that is 59 of the participants are working at secondary schools. Considering the distribution of the year of profession variable, it is seen that $25.2 \%$, that is 26 of the participants have been working for $1-5$ years; $31.1 \%$, that is, 32 of the participants have been working for 6-10 years; $11.7 \%$, that is 12 of them have been working for $11-15$ years and $32.0 \%$, that is 33 of them have been working for $16-20$ years.

Table 3. Results of $t$ test analysis made between gender variable and scale

\begin{tabular}{lllllll}
\hline Scale & Gender & Average & Standard Deviation & t test & p value & Difference \\
\hline Scale & Female & 62.51 & 9.50 & 1.565 & 0.121 & - \\
& Male & 59.78 & 7.29 & & & \\
\hline
\end{tabular}

As a result of the $t$ test analysis made between the scale and gender, no statistically significant relationship was found between the scale and gender $(p=0.121<\alpha=0.05)$.

Table 4. Results of $t$ test analysis made between institution variable and scale

\begin{tabular}{lllllll}
\hline Scale & Institution & Average & Standard Deviation & t test & p value & Difference \\
\hline Scale & Secondary School & 59.69 & 8.50 & -1.261 & 0.210 & - \\
& High School & 61.70 & 7.27 & & & \\
\hline
\end{tabular}

As a result of the $t$ test analysis made between the scale and institution variable, no statistically significant relationship was found between the scale and gender $(p=0.210<\alpha=0.05)$.

Table 5. Results of $t$ test analysis made between year of profession variable and scale

\begin{tabular}{lllllll}
\hline Scale & Year & Average & Standard Deviation & F test & p value & Difference \\
\hline Scale & $\mathbf{1 - 5}$ Years & 60.34 & 7.96 & 0.917 & 0.436 & - \\
& 6-10 Years & 62.37 & 9.21 & & & \\
& $\mathbf{1 1 - 1 5}$ Years & 60.08 & 6.20 & & & \\
& $\mathbf{1 6 - 2 0}$ Years & 59.12 & 7.39 & & & \\
\hline
\end{tabular}

As a result of the $t$ test analysis made between the scale and year of profession variable, no statistically significant relationship was found between the scale and year of profession $(p=0.436>\alpha=0.05)$.

\section{Discussion}

In this study, which examined the lifelong learning tendencies of physical education and sports teachers on different variables by using the "Lifelong Learning Scale" adapted to Turkish by Engin, Kör and Erbay (2016), no significant differences were found between the gender, year of profession and institution variables of physical education and sports teachers and lifelong learning scale. Some studies in the literature were not in line with the findings of this study.

In their study on lifelong learning motivation, Shin and Jun (2019) concluded that there was a significant difference between female and male teachers due to the fact that the female teachers had a higher learning motivation and their psychological readiness was better. Özçiftçi (2014) found in his study that there was a significant difference in favor of female teachers. In the study conducted by Diker and Çoşkun (2009), it was seen that the gender made a significant difference in the sub-dimensions of lifelong learning tendencies scale. This difference was in favor of female students. However, there was no difference in terms of gender in general lifelong learning tendencies. In the study of Şahin and Arcagök (2014); Yılmaz (2016); Yaman and Yazar (2015); and Yaman (2014), it was seen that the gender had no effect on lifelong learning skills. Atacanll (2007) found that self-learning levels did not differ in terms of gender. When the results of this study were examined, it had been seen that the results were contrast to the discourse of Jenkins (2004) on the genders. According to Jenkins (2004), the reasons why women value learning more and tend to learn more are due to their roles and responsibilities in family and community life, women have to change their job, quit their jobs or take long breaks and there is a concern that it would be insufficient for women to have equal competencies for men in 
professional promotion. Additionally, Jenkins (2004) stated that women benefit less from the education system than men, as well as gaining other characteristics, and stated that they attach more importance to participating in learning activities to meet their basic educational needs. There are also studies that support Jenkins (2004). Çetinkaya, Gülaçtı, Çiftçi and Kağan (2019) found significant differences between professional satisfaction and gender, which are the sub-dimensions of the lifelong learning scale they used in their studies. According to the result, it was concluded that male teachers had higher scores in the sub-dimension of professional satisfaction while female teachers had more tendencies in the sub-dimension of motivation, persistence, and regulation of learning and lack of curiosity. In parallel with these studies, Yılmaz et al. (2014), Dervişoğulları, Tutkun and Dervişoğulları (2016), Diker Coşkun and Demirel (2012), İzci and Koç (2012), Demirel and Akkoyunlu (2010), Evin-Gencel (2013), Şahin, Akbaşlı and Yanpar Yelken (2010), Demir Başaran and Sesli (2019), and Gökyer and Türkoğlu (2018) also concluded that the lifelong learning tendencies of female teachers were higher in general.

As a result of their research, Ayra, Kösterelioğlu and Çelen (2016) found that theachers' lifelong learning tendencies did not significantly differ in terms of their year of profession. This result is in parallel with our research findings. Based on the result obtained, one can make the comment that the duration of experience is not an effective factor in lifelong learning in general. Additionally, Şahin and Arcagök (2014); Diker Coşkun (2009); Ayaz (2016); Yılmaz (2016); Gökyer (2019); Kılıç (2015) and Özçiftiçi (2014) also stated that professional experience had no effect on many lifelong learning skills. Çetinkaya, Gülaçtı, Çiftçi and Kağan (2019) could not find significant differences in the results of variable analysis between the variables of seniority teachers and all sub-dimensions of lifelong learning tendencies and professional satisfaction. Contrary to these findings in the literature, Yaman (2014) found that teachers with 6-10 years of experience had higher lifelong learning tendencies than others. According to Duran and Tekin (2020), there was no significant difference in lifelong learning competencies of teachers according to their professional seniority. It was determined that the professional seniority of the teachers was not effective on the levels of lifelong learning competence. Although there was no significant difference when the average rank was considered, it was concluded that the lifelong learning competencies of the teachers with professional seniority of 6-10 years are higher than the others. In addition to Duran and Tekin (2020); and Yaman (2014), Yaman and Yazar (2015) concluded that the teachers with 6-10 years of professional seniority years had higher lifelong learning tendency scores. However, the lifelong learning tendency of teachers with 1-5 years of seniority were higher than the ones with $21+$ years of seniority, the lifelong learning tendency of teachers with 6-10 years of seniority were higher than the ones with 16-20 and 21+ years of seniority, and the lifelong learning tendency of teachers with 11-15 years of seniority were higher than the ones with $21+$ years of seniority. Looking at the result, it can be interpreted that the lifelong learning tendencies of teachers who have been working for 21 years or more may decrease due to professional deformation, fatigue and loss of motivation. The study findings of Demir, Başaran and Sesli (2019) support this interpretation.

Çetinkaya, Gülaçtı, Çiftçi, and Kağan (2019) could not find a significant difference between all sub-dimensions of teachers' lifelong learning tendencies and the institution they work at. This result is in parallel with the results of institution variable of our study. This result and the results of the research conducted by Dervişoğulları, Tutkun and Dervişoğulları (2016); Yılmaz (2016); and Çam and Üstün (2016) show similarity. Considering this result, it can be concluded that lifelong learning tendencies of the teachers, regardless of their levels, do not cause a significant difference and this is an important gain in terms of the quality of education.

In addition to the variable in our study, Ayra, Kösterelioğlu, and Çelen (2016) also performed an analysis between the branch, teaching profession attitudes, and the book-reading rate variable and the lifelong learning scale, and they found significant differences between teaching profession attitudes as well as whether they liked their profession or not, their reading rates and their lifelong learning tendencies. Based on these results, it can be conluded that teachers who love their profession may be more open to the developments on learning, and individuals who have the habit of reading books may be more open to learn new things since they keep their knowledge up-to-date and tend to read constantly. On the other hand, Durak and Tekin (2020) concluded that classroom teachers have higher lifelong learning competencies than branch teachers according to the branch variable. Çetinkaya, Gülaçtı, Çiftçi and Kağan (2019) could not find a significant relation between all sub-dimensions of lifelong learning and professional satisfaction scores and marital status variable. Besides, according to the variable analysis between the age variable, all sub-dimensions of lifelong learning tendencies and professional satisfaction, no significant differences were found. It can be interpreted with this situation that the lifelong learning tendency is not effected by the age and marital status variables. In his study, Y1lmaz (2016) could not find any significant differences between their lifelong learning tendency and settlement. 


\section{Conclusion and Recommendations}

According to the result of this study which aims to examine the lifelong learning tendencies of physical education and sports teachers through different variables, physical education teachers' lifelong learning tendency scores are high. At the same time, gender, professional seniority and the institution are not effective factors on the lifelong learning motivations of physical education and sports teachers. There are many studies in the literature that include the same and different variables, and the proportions of studies that support and do not support the effects of these variables on lifelong learning are almost equal. Based on this information, it can be expected that the lifelong learning tendency is actually a factor related to individuals' curiosity, motivation, and liking to learn, and it may be affected by different variable conditions or may not be affected at all. Wlodkowski (1993) explains this situation as; intrinsic motivation and emotional drives based on learning are required for lifelong learning to take place.

The following recommendations have been made within the framework of the findings and recommendations made as a result of this study;

1) Mixed studies that include qualitative, quantitative, and expansive explanations on lifelong learning tendency can be conducted.

2) It is a very common result that the lifelong learning motivations of female teachers are high. The source of the high motivation can be found out by handling this situation with qualitative methods.

3) Explanatory studies can be conducted on why physical education teachers are not affected in terms of gender, professional seniority and the institution they work for.

\section{References}

Arcagök, S., \& Şahin, Ç. (2014). An Investıgatıon of Teachers' Lifelong Learnıng Proficıency Level in Terms of Varıous Varıables. Adlyaman University Journal of Social Sciences Institute, 16, 394-417. https://doi.org/10.14520/adyusbd.705

Arcuria, P. (2011). Assessing Postsecondary Students' Orientation toward Lifelong Learning. Master Thesis. Arizona State University, December 2011.

Atacanli, M. F. (2007). Evaluation of the students lifelong learning behaviour change across years by the turkish version of the learning preference assessment (LPA) questionnaire at ankara university school of medicine. Health Sciences İnstitute, Master Thesis, Ankara University, Ankara.

Avrupa, K. (2002). European Report on Quality Indicators of Lifelong Learning. Brüksel, June, 2002. Retrieved March 15, 2013, from http://www.bolognaberlin2003.de/pdf/report.pdf adresinden alınmıştır

Ayaz, C. (2016). The analysis of life long learning tendencies of teachers in terms of some veriables. Bartin Bartin University/Institute of Educational Sciences/Department of Lifelong Learning and Adult Education. Master Thesis, Bartın.

Basaran, D. S., \& Sesli, Ç. (2019). Examination of Primary School and Middle School Teachers' Lifelong Learning Tendencies Based on Various Variables. European Journal of Educational Research, 3(8), 779-741. https://doi.org/10.12973/eu-jer.8.3.729

Budak, Y. (2009). The Human Type That Lifelong Learning and Primary Education Programs Should Target. Gazi University Journal of Gazi Education Faculty, 29(3), 693-708.

Çam, E., \& Üstün, A. (2016). The Relation Between Professional Attitude and Life Long Learning Tendency of Teachers. Hitit University Journal of Social Sciences Institute, 9(1), 459-476.

Candy, P. C. (1994). Developing lifelong learners through undergraduate education national board of employment, education and training. Canberra: Australian Government Publishing Service.

Cansever, B. A. (2009). Educational Policies of European Union and Evaluation of Turkey's Adaptation Process to These Policies. International Online Journal of Educational Sciences, 1(1).

Çetinkaya, B., Gülaçtı, F., Çiftçi, Z., \& Kağan, M. (2019). An Investıgation of Teachers’ Lifelong Learning Tendencies and Their Job Satisfaction in Terms of Various Variables. Trakya Journal of Education, 9(4), 809-823. https://doi.org/10.24315/tred.529759

Code, L. (2001). Lifelong Lerning in Master's Education. Yayınlanmamış Yüksek Lisans Tezi, Memorial University of Newfoundland, December, 2001.

Cornford, I. R. (2002). Learning to Learn Strategies as a Basis for Effective Llifelong Learning. International 
Journal of Lifelong Education, 21(4), 357-368. https://doi.org/10.1080/02601370210141020

Coşkun, Y. M., \& Demirel, M. (2012). Lifelong Learning Tendencies of University Student. Hacettepe University Journal of Education, 42, 108-120.

Dehmel, A. (2006). Making a European Area of Lifelong Learning a Reality? Some Critical Reflections on the European Union's Lifelong Learning Policies. Comperative Education, 42(1), 49-62. https://doi.org/10.1080/03050060500515744

Demiralay, R., \& Karadeniz, Ş. (2008). Developıng Informatıon Literacy Skılls for Lifelong Learnıng in Elementary Education. Cypriod of Journal Educational Sciencites, 2(6), 89-119.

Demirel, M. (2011). Reflections on life-long learning and primary education program in Turkey. Hacattepe University. International Journal of Educational Programs and Instructional Studies, 1(1), 87-105.

Demirel, M., \& Akkoyunlu, B. (2010). Pre-service teachers' lifelong learning tendencies and information literacy self-efficacy perceptions (vol. 2, pp. 1126-1133). 10th International Educational Technology Conference, Boğaziçi University, İstanbul, Proceedings Book.

Demirel, M., \& Yağc1, E. (2012). Classroom Teacher Candidates' Perceptions of Lifelong Learning. Hacettepe University Journal of Education Faculty, 1, 100-111.

Dervişoğulları, M., Tutkun, Ö. F., \& Dervişoğulları, M. (2016). Lifelong Learning Tendency Levels of the Teachers Who Work in Religious Vocational Secondary Schools and Religious Vocational High Schools. Route Educational and Social Science Journal, 3(5), 205-220. https://doi.org/10.17121/ressjournal.553

Dewey, J. (2004). Democracy and education (T. Göbekçin, Çev.). Ankara: Yeryüzü Yayınevi.

Diker, C. Y. (2009). Investigation of life long learning tendency of undergraduate students? in terms of some variables. Hacettepe University Institute of Social Sciences, Department of Educational Sciences Department of Education Programs and Teaching, Master Thesis, Ankara.

Diker, C. Y., \& Demirel, M. (2012). Lifelong Learning Tendencies of University Student. Hacettepe University Journal of Education, 42, 108-120.

Evin, G. İ. (2013). Prospective Teachers' Perceptions towards Lifelong Learning Competencies. Education and Science, 38(170), 237-254.

Fındıkçı, I. (2004). Education as you live. Istanbul: Hayat Publishing.

Gökyer, N. (2019). Lıfelong Learnıng Tendencies of Secondary School Teacher. Trakya University Journal of Social Science, 21(1), 145-159. https://doi.org/10.26468/trakyasobed.463102

Gökyer, N., \& Türkoğlu, İ. (2018). Lifelong Learning Trends of University Students. The Journal of International Social Sciences, 28(2), 125-136. https://doi.org/10.18069/firatsbed.460929

Günüç, İ., Odabaşı, H. F., \& Kuzu, A. (2012). Factors Affecting Lifelong Learning. Gaziantep University Journal of Social Sciences, 11(2), 309-325.

Gustafson, E. H. (1992). The Effectiveness of Teaching Lifelong Learning Skills to Students in A Community College Technical Program. Phd Thesis. Graduate Faculty of the School of Education United States International University, San Diego.

Harwood, A. (2007). Lifelong Learning: The Integration of Experiential Learning, Quality of Life Work in Communities, and Higher Education. Phd Thesis. The University of Montana, Spring 2007.

Jarvis, P. (2007). Globalisation, lifelong learning and the learning Society: Sociological Perspectives. London: Routledge. https://doi.org/10.4324/9780203964408

Jenkins, A. (2004). Women, lifelong learning and employment report. Centre for the economics of education. U.K. London School of Economics and Political Science.

Karasar, N. (2009). Scientific Research Methods (19th ed.). Ankara: Nobel Yayın Dağıtım.

Kılıç, H. (2015). Primary subject teachers' individual innovativeness levels and lifelong learning tendencies (Within Denizli province). Pamukkale University Institute of Educational Sciences, Denizli.

Knapper, C., \& Cropley, A. (2000). Lifelong learning in higher education. London: Kogan Page.

Kösterelioğlu, İ., Ayra, M., \& Çelen, Ü. (2016). Identifying the lifelong learning tendencies of the teachers in terms of different variables. Hitit University Institute of Social Sciences Journal, 9(1). 
Odabaş, H., \& Polat, C. (2008). The Key to Lifelong Learning in Information Society: Information Literacy. In globalization, democratization and Turkey International Symposium Proceedings, 27-30 Mart 2008.

Ohsako, T., \& Mauch, W. (2001). Revisiting Lifelong Learning for the 21st Century. Unesco Institute for Education. Retrieved March 10, 2013, from http://www.unesco.org/education/uie/pdf/revisitingLLL.pdf

Özçiftçi, M. (2014). Education with lifelong learning tendencies of classroom teachers. Relationship of self-efficacy towards technology standards. Unpublished Master's thesis, Amasya University, Institute of Social Sciences, Amasya.

Özden, Y. (2005). Learning and Teaching. Ankara: Pegem A Publishing.

Pepin, L. (2007). The History of EU Cooperation in the Field of Education and Training: How Lifelong learning Became a Strategic Objective. European Journal of Education, 42(1), 121-132. https://doi.org/10.1111/j.1465-3435.2007.00288.x

Sağlam, M., Özüdoğru, F., \& Çıray, F. (2011). The European Unıon Educatıon Polıcıes And Theır Effects Upon Turkısh Education System. Yüzüncü Yıl University. Journal of the Faculty of Education, 8(1), 87-109.

Şahin, M., Akbaşl1, S., \& Yanpar, Y. T. (2010). Key competences for lifelong learning: The case of prospective teachers. Educational Research and Review, 5(10), 545-556.

Shin, Y.-S., \& Jun, J. (2019). The hierarchical effects of individual and organizational variables on elementary school teachers lifelong learning competence. International Electronic Journal of Elementary Education, 12(2), 205-212. https://doi.org/10.26822/iejee.2019257668

Soran, H., Akkoyunlu, B., \& Kavak, Y. (2006). Life-Long Learning Skills and Training Faculty Members: A Project at Hacettepe University. Hacettepe University Journal of Education Faculty, 30, 201-210.

Uzunboylu, H., \& Hürsen, Ç. (2011). Lifelong Learning Compentence Scale (LLLCS): The Study of Valıdity and Reliability. H.U. Journal of Education, 41, 449-460.

Wlodkowski, R. J. (1993). Enhancing adult motivation to learn. San Francisco, CA: Jossey-Bass.

Yaman, F. (2014). Investigating of Life Long Learning Tendency of Teachers (The Example of Diyarbakır). Unpublished master's thesis, Dicle University, Diyarbakır.

Yaman, F., \& Yazar, T. (2015). Investigating of Life Long Learning Tendency of Teachers (The Example of Diyarbakır). Kastamonu Education Journal, 23(4), 1553-1566.

Yıldiz, D. H., \& Tekin, S. (2020). Analysis of the Lifelong Learning Competences of Teachers According to Personal and Professional Variables. Abant İzet Baysal University Journal of Education Faculty, 20(1), 221-235. https://doi.org/10.17240/aibuefd.2020.20.52925-547041

Yılmaz, F., Soğukçeşme, G., Ayhan, N., Tuncay, S., Sancar, S., \& Deniz, Y. (2014). Investigating Pre-Service Elementary Department Teachers' Professional Innovativeness Tendencies in Terms of Various Variables. Mustafa Kemal University Journal of Social Sciences Institute, 11(27), 259-276.

Y1lmaz, M. (2016). Examination of Teachers' Lifelong Learning Tendencies. Mustafa Kemal University Journal of Social Sciences Institute, 13(35).

\section{Copyrights}

Copyright for this article is retained by the author, with first publication rights granted to the journal.

This is an open-access article distributed under the terms and conditions of the Creative Commons Attribution license (http://creativecommons.org/licenses/by/4.0/). 